\title{
Addendum: Grenda et al. Clostridia in Insect Processed Animal Proteins-Is an Epidemiological Problem Possible? Agriculture
} $2021,11,270$

\author{
Tomasz Grenda ${ }^{1, *(D)}$, Krzysztof Kwiatek ${ }^{1}$, Magdalena Goldsztejn ${ }^{1}$, Magdalena Sapała ${ }^{1}$, Nina Kozieł ${ }^{1}$ \\ and Piotr Domaradzki ${ }^{2} \mathbb{D}$ \\ 1 Department of Hygiene of Animal Feeding Stuffs, National Veterinary Research Institute, Partyzantow 57, \\ 24-100 Pulawy, Poland; kwiatekk@piwet.pulawy.pl (K.K.); magdalena.kozak@piwet.pulawy.pl (M.G.); \\ magdalena.grabczak@piwet.pulawy.pl (M.S.); nina.koziel@piwet.pulawy.pl (N.K.) \\ 2 Department of Commodity Science and Animal Raw Materials Processing, University of Life Sciences in \\ Lublin, Akademicka 13, 20-950 Lublin, Poland; piotr.domaradzki@up.lublin.pl \\ * Correspondence: tomasz.grenda@piwet.pulawy.pl
}

check for updates

Citation: Grenda, T.; Kwiatek, K.;

Goldsztejn, M.; Sapała, M.; Kozieł, N.; Domaradzki, P. Addendum: Grenda et al. Clostridia in Insect Processed Animal Proteins-Is an

Epidemiological Problem Possible? Agriculture 2021, 11, 270. Agriculture 2021, 11, 549. https://doi.org/ 10.3390/agriculture11060549

Received: 2 June 2021

Accepted: 9 June 2021

Published: 16 June 2021

Publisher's Note: MDPI stays neutral with regard to jurisdictional claims in published maps and institutional affiliations.

Copyright: (c) 2021 by the authors. Licensee MDPI, Basel, Switzerland. This article is an open access article distributed under the terms and conditions of the Creative Commons Attribution (CC BY) license (https:// creativecommons.org/licenses/by/ $4.0 /)$.
The following should be added to the Acknowledgments section of this paper [1]:

The authors would like to express their deep gratitude to Wiesław Sobotka from the University of Warmia and Mazury for sharing the data concerning the recipes of compound feeds included in Tables 3 and 4, with the corresponding nutritional composition in Tables 5 and 6 enclosed in the Materials and Methods section. Simultaneously, the authors emphasise that the mentioned data are the intellectual property of Wiesław Sobotka from the Department of Animal Nutrition and Feed Science, University of Warmia and Mazury in Olsztyn, Oczapowskiego 5, 10-719 Olsztyn, Poland.

\section{Reference}

1. Grenda, T.; Kwiatek, K.; Goldsztejn, M.; Sapała, M.; Kozieł, N.; Domaradzki, P. Clostridia in Insect Processed Animal Proteins-Is an Epidemiological Problem Possible? Agriculture 2021, 11, 270. [CrossRef] 